International Journal of Development and Economic Sustainability

Vol.10, No.1, pp.1-12, 2022

ISSN: 2053-2199 (Print),

ISSN: 2053-2202(Online)

\title{
OWNERSHIP STRUCTURE AND FIRM PERFORMANCE OF LISTED CONSUMER GOODS SECTOR FIRMS IN NIGERIA
}

\author{
Lyndon M. Etale (Ph.D) and Boloumbele Yalah \\ Department of Accounting, Faculty of Management Sciences, Niger Delta University, \\ Wilberforce Island, Bayelsa State, Nigeria
}

\begin{abstract}
The study investigated the ownership structure and financial performance of listed consumer goods sector firms in Nigeria for the period of 2011-2020. The data were gathered from the published financial statements of consumer goods sector firms with return on asset serving as dependent variable while controlling ownership and non-controlling ownership were used as explanatory variables, and analyzed through the descriptive statistics; correlation analysis, panel regression and fixed and random effect regression. The result revealed that ownership structure has robust relationship with financial performance. The study concluded that controlling ownership has positive and non-statistical significant with financial performance while non-controlling ownership has positive and statistical significant relationship with financial performance of listed consumer goods firms in Nigeria. The study recommended that firms listed under the sector should imbibe the corporate governance long run strategies to increase the organizational growth.
\end{abstract}

KEYWORDS: controlling ownership, financial performance, non-controlling ownership, return on asset

\section{INTRODUCTION}

The financial performance of some companies is basically related to the ownership structure, as they can be funded through capital. In general, companies have a mission to generate profits. This responsibility is very important because the ability of a company to generate profits in a highly competitive market primarily determines its future viability (Alhassan \& Memunda, 2020). Bacha and Attia (2016) added that financial performance as a tool to measure how much a company uses resources to make a profit, making it an essential tool for many stakeholders in a company. Therefore, financial performance is important for the survival of any business and the continued sponsorship of potential and existing investors, creditors, and other stakeholders in the business world. Similarly, the financial performance represent the financial health of the company, although when analyzing financial performance, care must be taken to properly explain the concept of financial performance and reveal various aspects of assessing a company's financial performance. When it comes to measurement, most scholars measure financial performance differently.

@ECRTD-UK: https://www.eajournals.org/

https://doi.org/10.37745/ijdes.13 
Ownership structure related to financial performance is an important discussed in the corporate finance literature. In certain aspect, the interests of management and shareholders do not match, causing problems that reduce the value and financial performance of the company (Tatiana \& Stela, 2013) as in Ironkwe \& Emefe, 2020). Shareholders are always considered business owners, and directors are agents or representatives of shareholders who are to use their business resources to increase their assets (Benjamin, Love \& Kabiru2014). Beni \& Alexander (1999) found that owner-managed companies are more efficient than non-owner-managed companies because owner-managers own shares in the company, whereas non-owner-owned companies are non-owners. It is perceived that managers have their personal benefits at the expense of other shareholders and the entire organization.

Over the last two decades, the liquidation of reputable companies such as Enron and WorldCom in the United States has significantly changed the concentration of ownership in relation to the mechanism of ownership structure. This trend has been repeated around the world, including the collapse of Parmalat in Europe, Aoyama in Asia, Cadbury Nig., Sky Bank both in Nigeria, in Kenya, the likes of Utsumi Imperial Bank and Chase Bank (Ongore \& K Obonyo, 2011). The corporate high failures gave the spotlight on the importance of various concentration of ownership that affects the profitability of a business.

Jiang (2015) posited that ownership Concentration is a key component of in the current corporate governance structure. In order to promote the growth of the business, the owner of the business (in principle) must transfer the operating rights of the business to a qualified agent to operate the business and retain control. Conflicts of interest between the owner and the manager bring about a selfish attitude of the manager of short-term profits that affects the well-being of the principal by extending the compulsory contract. Affan, Rossidiand and Purwanti (2017), ownership structure is determined by voting, capital, and distribution of shares regarding shareholder identities. In this way, the ownership structure of a company is a major factor in its financial performance.

Similarly, the study of Nganga (2017) believed that directors and management are working to integrate welfare outcomes into a structural-performance framework aimed at increasing business efficiency and reduce agency competition and maximize company wealth creation. Therefore, the firm's manager needs to take responsibility to ensure that the company's resources are optimized to generate reasonable profits.

The study considered the impact of ownership structure and financial performance, ownership structure proxied by controlling interest and non-controlling interest while financial performance was expressed using the return on asset. This aspect has been extensively studied in developed countries, and more recently in emerging economies, but has received less attention in the Nigerian context.

@ECRTD-UK: https://www.eajournals.org/

https://doi.org/10.37745/ijdes.13 


\section{Objectives of the Study}

The main aim and objective of this research work are to examine the link between ownership structure and firm performance of listed consumer goods sector firms in Nigeria.

The specific objectives of the study are to:

(i) Investigate the influence of controlling ownership on return on asset of listed consumer goods sector firms in Nigeria.

(ii) Evaluate the impact of non-controlling ownership on return on asset of listed consumer goods sector firms in Nigeria.

\section{Research Questions}

The following research questions were stated for the study;

(i) What is the influence of controlling ownership on return on asset of listed consumer goods sector firms in Nigeria?

(ii) What is the impact of non-controlling ownership on return on asset of listed consumer goods sector firms in Nigeria?

\section{Research Hypotheses}

The research hypotheses were stated in the null hypotheses;

$\mathrm{H}_{01}$ : Controlling ownership does not significantly influence the return on asset of listed consumer goods sector firms in Nigeria.

$\mathrm{H}_{02}$ : Non-Controlling ownership does not significantly influence the return on asset of consumer goods sector listed firms in Nigeria.

\section{LITERATURE REVIEW}

\section{Ownership Structure}

\section{Controlling Ownership}

Shareholders own control of the company if they own $50 \%$ or more of the voting shares of the company. This gives them the ultimate voice in managing shareholders' meetings and corporate governance. Voting shares allow shareholders to attend, speak and vote at shareholders' meetings. If another shareholder owns more of the company's approved, issued, and issued

@ECRTD-UK: https://www.eajournals.org/

https://doi.org/10.37745/ijdes.13 
shares and is interested in the company, but those shares do not have voting rights, then that shareholder is in management or governance. It cannot influence the decision.

\section{Non-controlling ownership}

Non-controlling (minority interests) exist when the ownership interest is less than $50 \%$ of the outstanding voting shares. However, the threshold may be lower because shareholders can only own $49 \%$ of the company and can guide the company's decisions through the management of the board of directors. Most listed companies classify most shareholders as non-controlling interests because most shareholders have a broad shareholder base. Only if the investor holds 5\% to 10\% of the total number of issued shares can the change be made significantly by requesting a seat on the board of auditors or publicly advocating at a general meeting of shareholders. ..

\section{Financial Performance}

There is no universal definition of financial capacity. The financial position of a company is used to represent the state of the company. When analyzing a company's financial performance, the emphasis should be on creating a good description of the company's financial performance concept and revealing various aspects of assessing the company's financial performance. Scholars have several dispositions on financial measurement; see Demstz and Lehn (2001) measured a company's financial performance as an accounting rate of return. Kechi (2011) measured a company's financial performance in terms of return on assets (ROA) and net profit margin (NPM). Similarly, Fazlzadeh, et al. (2011) asserted that measurement of a company's financial performance as net income related to total assets and ordinary income related to total assets. Uwaloma and Olamide (2012) measured a company's financial performance in terms of return on assets (ROA). Okewale, Mustapha and Aina (2020) measured financial performance as return on equity, which was measured by the ratio of after-tax profit to total capital to carrying amount. Although, this study posited that financial performance relates to return on asset.

Figure 1 shows the conceptual framework that financial performance measured by return on assets of the listed consumer goods firms is affected by controlling ownership and noncontrolling ownership

@ECRTD-UK: https://www.eajournals.org/

https://doi.org/10.37745/ijdes.13 


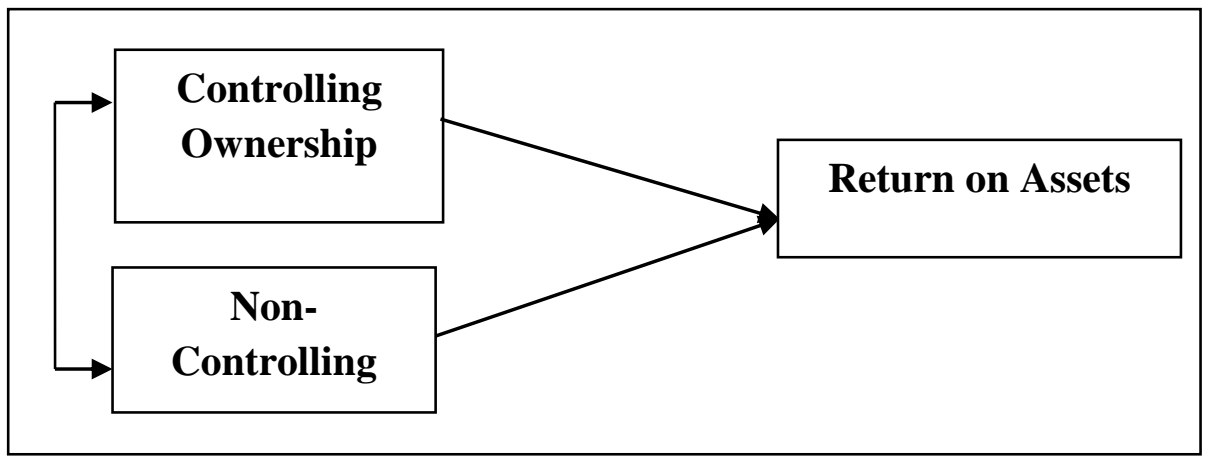

Fig. 1: Conceptual Framework

\section{Theoretical Framework}

The study hinges on agency theory. This study examined the conflicts between agency theory, and how such conflicts affect a company's financial performance. The agency theory was developed by Jensen and Meckling (1976) and is based on the assumption that the role of an organization is to maximize the wealth of shareholders (Blair, 1995). In addition, agency theory explains the fundamental problem for absent or distant owners who hire professional executives to act on their behalf. Eisenhardt (1989) states that "most companies operate in incomplete and uncertain situations and are exposed to two behavioral issues: negative selection and moral risk. Moral hazard is a state in which the agent is uncertain that he or she has made the utmost effort, while adverse selection is the owner of whether the agent correctly portrays the ability of the agent to perform the paid work.

According to Wheelen and Hunger (2002), the agent (expert) does not own a substantial stake in the company and therefore cannot benefit from pursuing the goal of maximizing wealth. The problem arises because the expert is not responsible for the decision. Therefore, this study focuses on the relationships between shareholders and their professional representatives in various ownership structures and how they affect the financial performance of listed companies in Nigeria.

\section{Empirical Review}

Gabriel and Osazuwa (2020) investigated the impact of concentration of ownership structure on the financial performance of Nigerian manufacturing firms from 2009 to 2019, The data were gathered and regressed using the cointegration test and GMM system. From the analysis output, the results revealed that government owned concentration, block ownership concentration, and institutional ownership concentration all have a significant impact (direct and vice versa) on the performance indicators (ROA, TOBIN Q) used in the study. Based on this, the study suggested that policy makers and governments to make balanced investments in all categories of investors, and it is advisable to create favorable policies to ensure growth among the few owners who are

@ECRTD-UK: https://www.eajournals.org/

https://doi.org/10.37745/ijdes.13 
International Journal of Development and Economic Sustainability

Vol.10, No.1, pp.1-12, 2022

ISSN: 2053-2199 (Print),

ISSN: 2053-2202(Online)

attracting skills and abilities and improving performance. The government also needs to maintain stakes in foreign and local businesses to increase shareholder trust.

Alhassan and Mamuda (2020) explored the effect of ownership structure on the financial performance of quoted financial firms in Nigeria for the periods of 2010 to 2019. The study selected data from thirty eight financial firms listed in Nigeria. The data were regressed using the pooled General Least Square, Random and Fixed Effects regression model in testing the hypotheses of the study. From the analytical output, the study found that ownership structure has positive significant effect on financial performance of the quoted financial firms except ownership concentration having negative effect on financial performance. The study suggested that a financial firm needs to expand their managerial equity ownership.

Okewale, Mustapha and Aina (2020) examined the ownership structure and its financial performance of 18 food and beverage companies listed on the Nigerian Stock Exchange (NSE) between 2010 and 2018. The study uses secondary data and was obtained from the company's annual reports and financial statements. The data collected was analyzed using pooled regression, fixed-effects regression, and random effects. The results showed that management ownership had a insignificant (positive) impact on return on equity $(\mathrm{t}=1.63 ; \mathrm{P}=0.329 ; \mathrm{P}$ > 0.05). Employee ownership had a significant positive effect on return on equity.

In the study of Ogaluzor (2019) evaluated the share rights acquisition and profitability of quoted companies in NSE. The study gathered data from twenty quoted firms for the annual published report of 2016. The Generalised Least Square (GLS) regression technique was employed to analyze the results and the revealed a negative significant relationship between rights acquisition and profitability. This study was contradictory after findings of both positive relationships among rights acquisition and managerial share possession with firm profitability and the study was limited to one set of ownership concentration identity.

Ironkwe and Emefe (2019) explored corporate ownership structure and financial performance for the period of 2008-2017. The study data were analyzed using the ordinary least square regression which found that there is positive and significant relationship between ownership concentration and return on equity. They suggested that shareholders and management need to enhance their strategic planning decision making process.

Lawal et al. (2018) investigated the impact of ownership structure on the performance of 28 listed insurance companies in Nigeria. Data were collected from the annual reports of 28 insurance companies listed on the Nigerian Stock Exchange between 2011 and 2016. ExpostFacto was used in a study to assess the impact of ownership structure on the performance of Nigerian listed insurance companies. In addition to descriptive statistics and correlation, a multiple regression method based on the panel data method was used for model estimation. The data were run on a pooled regression model of common least squares, fixed effects, and random effects to test the research hypothesis. The ownership structure, represented by managerial ownership, institutional ownership, and ownership concentration, has been adopted as an

@ECRTD-UK: https://www.eajournals.org/

https://doi.org/10.37745/ijdes.13 
independent variable. The book value per share is listed as a dependent variable. The study found that the ownership structure has a significant positive impact on the performance of listed insurance companies. However, concentration of ownership has a negative impact.

Ahmed and Hadi (2017) investigated the impact of ownership structure on the financial performance of companies in the MENA region. The sample includes nine MENA countries in 2014 (Egypt, Bahrain, Qatar, Kuwait, Tunisia, United Arab Emirates, Morocco, Oman and Jordan). Outcomes are represented by insider ownership, government, and block owners. Manage survey risk, size, country impact, and industry type. This result suggests that blockholder, insider ownership, and government ownership play important roles in business performance as measured by TobinQ, ROE, and ROA, respectively. This result suggests that insider ownership has a negative impact on a company's return on equity, and block owner ownership has a positive impact on a company's TobinQ.

\section{METHODOLOGY}

\section{Research Design}

The study adopts the causal research design to explore the effect of ownership structure and firm performance of listed consumer goods firms in Nigeria. The study adopt the secondary source of data which the researcher has no control or could manipulate based on the fact that the event had already occurred. The study population was twenty one (21) consumer goods firms listed in Nigeria. The study sample of fifteen (15) Cadbury Nig, Champion Breweries, Dangote Sugar, Flour Mills Of Nigeria, Guinness Nig, Honywell Flour Mill, International Breweries, Mcnichols Consolidated, Nascon Allied, Nestle Nig, Nigeria Breweries, Nigerian Enamelware, Nigerian Northen Flour Mill, Unilever Nig, Pz Cussons consumer goods firms were purposively selected due to access to their published financial statement for the period of 2011-2020.

\section{Model Specification}

In order to test for the correlation between ownership structure and firm Performance of listed firms in Nigeria, the following multiple regression model was adopted see (Gabriel \& Osazuwa, 2020): The model incorporating the dependent variable, financial performance were measured as (ROA) and the independent variable (Ownership structure) decomposing into controlling ownership, non-controlling ownership;

Yit $=\beta 0+\mathrm{Bx}_{1}+\mathrm{Bx}_{2}+\mu l$

$\mathrm{ROA}=f(\mathrm{CO}, \mathrm{NCO}, \mathrm{FSZE})$

The econometric form of the models is stated below as:

ROAit $=\beta o+\beta_{1} \mathrm{CO}+\beta_{2} \mathrm{NCO}+\beta_{3} \mathrm{FSZE}+\mu 1 \ldots \ldots$ (3)

Where;

@ECRTD-UK: https://www.eajournals.org/

https://doi.org/10.37745/ijdes.13 
$\mathrm{ROA}=$ represented by return on asset

$\mathrm{CO}=$ Controlling Ownership

$\mathrm{NCO}=$ Non-Controlling Ownership

$\mathrm{FSZE}=$ Log of Total Asset.

$\beta$ o to $\beta_{3}=$ Coefficient of the variables

$\mu 1=$ error term

Size of firm was introduced as a control variable to avoid arriving at an invalid result because it is a major determinant of the profit of such firm.

\section{RESULTS AND DISCUSSION OF FINDINGS}

Table 1: $\quad$ Descriptive Statistics

\begin{tabular}{lcccc}
\hline & ROA & CO & NCO & FSZE \\
\hline Mean & 5.773866 & 64.87333 & 32.92667 & 7.553455 \\
Median & 4.889150 & 67.00000 & 33.00000 & 7.774400 \\
Maximum & 26.49350 & 87.00000 & 50.00000 & 8.683600 \\
Minimum & -43.33510 & 24.00000 & 13.00000 & 5.351300 \\
Std. Dev. & 9.007478 & 14.04991 & 9.398055 & 0.805744 \\
Skewness & -0.939632 & -1.416980 & -0.023329 & -0.821700 \\
Kurtosis & 8.382989 & 5.301016 & 2.044347 & 3.024798 \\
& & & & \\
Jarque-Bera & 203.1763 & 83.28756 & 5.721556 & 16.88360 \\
Probability & 0.000000 & 0.000000 & 0.057224 & 0.000216 \\
& & & & \\
Sum & 866.0799 & 9731.000 & 4939.000 & 1133.018 \\
Sum Sq. Dev. & 12089.06 & 29412.59 & 13160.19 & 96.73438 \\
Observations & 150 & 150 & & 150 \\
\hline Source: E-view & $\mathbf{C u t p u t}$ & & & \\
\hline
\end{tabular}

Source: E-view Output

The minimum and maximum value of ROA are (-43.33510) \& (26.49350) respectively, whereas the mean value is (5.773866) and standard deviation is (9.007478). $\mathrm{CO}$ has minimum and maximum value of (24.00000) \& (87.00000) respectively, with a mean value of (64.87333) and standard of (14.04991). NCO has minimum and maximum value of (13.00000) \& (50.00000) respectively, with a mean value of (32.92667) and standard deviation of (9.398055). FSZE has minimum and maximum value of (5.351300) \& (8.683600) respectively; with a mean value of (7.553455) and standard deviation of (0.805744).

The descriptive statistics result showed that the variables ROA, CO, NCO and FSZE are downward skewed negatively skewed. Therefore, we conclude the distribution to be approximately normal. The coefficient of the kurtosis of ROA, CO, NCO and FSZE indicates mesokurtic given that the kurtosis values are approximately 3.00, relative to the normal; thus they are normally distributed.

@ECRTD-UK: https://www.eajournals.org/

https://doi.org/10.37745/ijdes.13 
Table 2: Correlation Matrix of the Variables

\begin{tabular}{c|rrrr}
\hline \hline $\begin{array}{l}\text { Correlation } \\
\text { Probability }\end{array}$ & ROA & CO & NCO & FSZE \\
\hline ROA & 1.000000 & & & \\
& ---- & & & \\
CO & -0.094433 & 1.000000 & & \\
& 0.2504 & ---- & & \\
NCO & 0.105196 & -0.853624 & 1.000000 & --- \\
& 0.2001 & 0.0000 & & \\
& & & & \\
FSZE & 0.123789 & 0.479941 & -0.208452 & 1.000000 \\
& 0.1312 & 0.0000 & 0.0105 & ---- \\
\hline \hline
\end{tabular}

Table 2 reveals the correlation within the explanatory variables themselves. The values were obtained from the Pearson correlation. The Table shows that positive relationships exist between the dependent variables represented by the return on asset (ROA) and the explanatory variables represented by controlling ownership (CO) and Non-controlling ownership (NCO). It is observed that (NCO) had positive relationships with return on asset. While, controlling ownership has negative relationship with return on asset.

Table 3: Regression Result

\begin{tabular}{lrlrr}
\hline \hline \multicolumn{1}{c}{ Variable } & Coefficient & Std. Error & t-Statistic & Prob. \\
\hline \multicolumn{1}{c}{ CO } & 0.123418 & 0.184490 & 1.494836 & 0.1371 \\
NCO & 3.002805 & 1.800877 & 2.217144 & 0.0346 \\
FSZE & 2.718653 & 1.146168 & 2.371951 & 0.0190 \\
\multicolumn{1}{c}{ C } & 0.039661 & 11.05380 & 0.003588 & 0.9971 \\
\hline \hline R-squared & 0.473837 & Mean dependent var & 5.773866 \\
Adjusted R-squared & 0.328272 & S.D. dependent var & 9.007478 \\
S.E. of regression & 8.879234 & Akaike info criterion & 7.231612 \\
Sum squared resid & 11510.76 & Schwarz criterion & 7.311896 \\
Log likelihood & -538.3709 & Hannan-Quinn criter. & 7.264229 \\
F-statistic & 2.445048 & Durbin-Watson stat & 0.437875 \\
Prob(F-statistic) & 0.000342 & & \\
\hline \hline
\end{tabular}

The Overall cumulative R2 value of 0.4675 which is the multiple coefficient of determination shows the portion of the entire variation in the dependent variable described by the explanatory variables jointly. Hence, it signifies that $47 \%$ of the total disparity in return on asset of listed consumer goods firms in Nigeria attributable to controlling ownership and non-controlling

@ECRTD-UK: https://www.eajournals.org/

https://doi.org/10.37745/ijdes.13 
International Journal of Development and Economic Sustainability

Vol.10, No.1, pp.1-12, 2022

ISSN: 2053-2199 (Print),

ISSN: 2053-2202(Online)

ownership. Similarly, the regression results revealed that the Adjusted R2 is 0.328. This means that ownership structure of the listed consumer goods firms contributes about $33 \%$ to companies' financial performance which was proxy by ROA.

\section{Table 4: Hausman Test}

Correlated Random Effects - Hausman Test

Equation: Untitled

Test cross-section and period random effects

\begin{tabular}{lrrr}
\hline \hline Test Summary & $\begin{array}{c}\text { Chi-Sq. } \\
\text { Statistic }\end{array}$ & Chi-Sq. d.f. & Prob. \\
\hline \hline Cross-section random & 14.644608 & 3 & 0.0021 \\
Period random & 0.000000 & 3 & 1.0000 \\
Cross-section and period random & 19.994964 & 3 & 0.0002 \\
\hline \hline
\end{tabular}

* Period test variance is invalid. Hausman statistic set to zero.

Cross-section random effects test comparisons:

\begin{tabular}{crrrr} 
Variable & Fixed & Random & $\operatorname{Var}$ (Diff.) & Prob. \\
\hline \hline CO & -1.274695 & -0.006900 & 0.619236 & 0.1072 \\
NCO & -1.324680 & 0.012834 & 0.616260 & 0.0884 \\
FSZE & -9.369174 & -1.502061 & 4.316042 & 0.0002 \\
\hline \hline
\end{tabular}

Effects Specification

\begin{tabular}{lrll}
$\begin{array}{l}\text { Cross-section fixed (dummy variables) } \\
\text { Period fixed (dummy variables) }\end{array}$ & \\
\hline \hline & 0.605199 & Mean dependent var & 5.773866 \\
R-squared & 0.521746 & S.D. dependent var & 9.007478 \\
Adjusted R-squared & 6.229205 & Akaike info criterion & 6.657924 \\
S.E. of regression & 4772.769 & Schwarz criterion & 7.199838 \\
Sum squared resid & -472.3443 & Hannan-Quinn criter. & 6.878086 \\
Log likelihood & 7.251913 & Durbin-Watson stat & 0.820212 \\
F-statistic & 0.000000 & & \\
Prob(F-statistic) & & & \\
\hline \hline
\end{tabular}

Source: E-view Output, 2021

The result from Table 5 shows the Hausman test that was used to test the Fixed/Random Effects and to ascertain the appropriate model. The null hypothesis represents the Random Effects Model at ( $>>0.05)$, while the alternate hypothesis represents the Fixed Effect Model at $(\mathrm{p}<0.05)$.

@ECRTD-UK: https://www.eajournals.org/

https://doi.org/10.37745/ijdes.13 
From the Hausman test, the result revealed that the p-value of $(0.0021)$ which is lesser than $0.05 \%$. The result shows that the Fixed Effects Model is a better model for the above relationship than the Random Effect Model.

From the OLS statistical analytical outputs in Table 3, the following inferences are deduced from the ownership structure and firm performance:

1. Controlling ownership $(\mathrm{CO})$ has a positive and insignificant impact on return on asset (ROA) with a coefficient of 0.123418 and a p-value of 0.1371 . This result is consistent with the work of (Ahmed and Hadi, 2017), While, it is inconsistent with the findings of (Alhassan and Mamuda (2020).

2. Non-controlling Ownership (NCO) has a positive and significant relationship with return on asset; with a coefficient of 3.002805 and a p-value of 0.0346 . The result is consistent with the findings of (Lawal et al. 2018; Ironkwe and Emefe 2019 Alhassan and Mamuda 2020) and negates the findings of (Ahmed and Hadi, 2017).

Also, the control variable introduced; firm size (FSZE) also revealed that positive effect and significant relationship with return on asset (ROA). The result advocates that the control variable partially increases the possibility of return on asset of listed consumer goods companies in Nigeria. The finding is in line with Suleiman, Jamilu \& Jamilu (2020).

\section{CONCLUSION AND RECOMMENDATION}

The study investigated the ownership structure and financial performance of listed consumer goods firms in Nigeria for the period of 2011-2020. The data were gathered from the published financial statement of the firms and analyzed through the descriptive statistics, correlation analysis and the coefficient determination revealed that ownership structure has robust relationship with financial performance. The study concluded that controlling ownership has positive and non-statistical significant with financial performance while non-controlling ownership has positive and statistical significant relationship with financial performance of listed consumer goods firms in Nigeria. The study recommended that firms in the consumer goods sector should imbibe the corporate governance long run strategies to increase the organizational growth

\section{REFERENCES}

Affan, W. M., Rosidi, S. E. \& Purwanti, L. (2017). The effect of ownership structure on the quality of financial reporting of manufacturing companies listed in the IDX. Imperial Journal of Interdisciplinary Research 3(7), $34-46$.

@ECRTD-UK: https://www.eajournals.org/

https://doi.org/10.37745/ijdes.13 
International Journal of Development and Economic Sustainability

Vol.10, No.1, pp.1-12, 2022

ISSN: 2053-2199 (Print),

ISSN: 2053-2202(Online)

Alhassan, I. \& Mamuda, A. U. (2020). Ownership structure and financial performance of quoted financial firms in Nigeria. International Journal of Accounting Research, 5(4); 116-124.

Bacha, S \& Attia, T. (2016). Ownership structure, financial communication quality and debt cost: An empirical study of Tunisian listed companies. International Journal of Business and Financial Management Research, 4(6) 109-116.

Benjamin, K. G., Love, O. A. \& Kabiru, D. (2014). The Impact of Ownership Structure on the Financial Performance of Listed Insurance Firms in Nigeria, International Journal of Academic Research in Accounting, Finance and Management Sciences, 4(2),409- 416.

Demsetz, H., \& Villalonga, B. (2001). Ownership structure and corporate performance. Journal of Corporate Finance, 7(1),209- 233.

Fazlzadeh, A., Hendi, A. T., \& Mahboubi, K. (2011). The examination of the effect of ownership structure on firm performance in listed firms of Tehran stock exchange based on the type of the industry. Interactional Journal of Business and Management, 6(3), 249-267.

Gabriel, A. M. \& Osazuwa, E. J. (2020). Ownership concentration and financial performance of manufacturing firms in Nigeria. African Journal of Management, 5(3); 60-78.

Ironkwe, U. I and Emefe, P. (2019). Corporate ownership structure on financial performance of quoted companies in Nigeria. International Journal of Advanced Academic Research, $5(4) ; 67-87$.

Jiang, P. (2015). The relationship between ownership structure and firm performance: An empirical analysis over Heilongjiang listed companies. Nature and Science, 2(4), 87-90.

Jensen, M \& Meckling, W, (1976). Theory of the firm: managerial behavior, agency costs, and ownership structure. Journal of Financial Economics 3(6), 305-360.

Lawal, O. D., Agbi, E. S. \& Mustapha, L. O. (2018). Effect of ownership structure on financial performance of listed insurance firms in Nigeria. Journal of Accounting, Finance and Auditing Studies, 4(3), 123-148.

Nganga, N.P. (2017). Effect of ownership structure on financial performance of companies listed at the Nairobi securities exchange in Kenya. A thesis submitted in partial fulfilment for the degree of doctor of philosophy in business administration (finance) in the Jomo Kenyatta University of Agriculture and Technology, Kenya.

Okewale, J. A., Mustapha, O. A. \& Aina, G. O. (2020).Ownership structure and financial performance of quoted food and beverage firms in Nigeria, KIU Journal of Social Sciences, 6(2); 263-273.

Ongore, O., \& K'Obonyo, O. P. (2011). Implications of firm ownership identity and managerial discretion on financial performance: Empirical evidence from Nairobi stock exchange. International Journal of Humanities and Social Science, 13(1), 136-156.

Tatiana, V. \& Stella, B. (2013). Ownership structure and Company performance: Research and Literature review, Financial Internet Quarterly, 9(3),55-56.

Wheeler, D., Colbert, B., \& Freeman, E. (2003). Focusing on Value: Reconciling corporate social responsibility, sustainability and a stakeholder approach in a network world. Journal of General Management, 1-28.

@ECRTD-UK: https://www.eajournals.org/

https://doi.org/10.37745/ijdes.13 